\title{
Neuroectoderm in Drosophila embryos is dependent on the mesoderm for positioning but not for formation
}

\author{
Yi Rao, ${ }^{1}$ Harald Vaessin, Lily Y. Jan, and Yuh-Nung Jan \\ Howard Hughes Medical Institute, Departments of Physiology and Biochemistry, University of California at San Francisco, \\ San Francisco, California 94143-0724 USA
}

\begin{abstract}
By studying neuroectoderm formation in the absence of mesoderm and mesectoderm in mutants of the zygotic genes snail and twist, we have found that the number of neuroblasts is not reduced in these mutants, suggesting that mesoderm and mesectoderm are not essential for the initiation of neural development. The position of the neuroectoderm, however, is ventrally shifted: Neuroectoderm takes over the presumptive peripheral mesoderm domain in single mutants, whereas the entire presumptive mesoderm domain in double mutants takes on the neuroectodermal fate. The shifted neuroectoderm still requires the proneural genes and the neurogenic genes. This shift is unlikely to be due to any shift in the nuclear localization gradient of the maternally supplied dorsal protein. A model for cell fate determination of the neuroectoderm, mesectoderm, and mesoderm will be discussed.
\end{abstract}

[Key Words: Neurogenesis; induction; mesoderm; neuroectoderm; snail; twist]

Received June 11, 1991; revised version accepted July 19, 1991.

The central nervous system of Drosophila originates from the ventrolateral neurogenic regions (the neuroectoderm) of the embryo (Poulson 1950; Campos-Ortega and Hartenstein 1985). In the blastoderm, neurogenic regions are separated from the mesoderm in the ventral region by one row of mesectodermal cells. During gastrulation, the mesodermal cells invaginate, eventually lying under the neurogenic, as well as the more dorsal, ectoderm, whereas the mesectodermal cells on the two sides of the embryo are brought to the ventral midline. The determination of neuroblasts requires the activity of at least two groups of genes in the neuroectoderm: the proneural genes, including daughterless $(d a)$ and genes of the achaete-scute complex (AS-C), which give groups of cells, the proneural clusters, the potential to become neuroblasts (Campuzano et al. 1985; Dambly-Chaudiere and Ghysen 1987; Villares and Cabrera 1987; Caudy et al. 1988; Ghysen and Dambly-Chaudiere 1988), and the neurogenic genes, such as Notch $(N)$ or Delta $(D I)$, which allow only subsets of cells of the proneural clusters to become neuroblasts (Lehmann et al. 1983; Wharton et al. 1985; Kidd et al. 1986; Vaessin et al. 1987; Kopczynski et al. 1988; for reviews, see Artavanis-Tsakonas 1988; and Campos-Ortega and Jan 1991).

Whether genes expressed in non-neuroectodermal cells can affect the formation or patterning of the neuroblasts is not known. The physical proximity of the neuroectoderm to the mesoderm raises the question as

${ }^{1}$ Present address: Department of Biochemistry and Molecular Biology, Harvard University, Cambridge, Massachusetts 02138 USA. to whether the neural tissue could be induced by the mesoderm, as has been found in vertebrates (Spemann 1938; Gurdon 1987; Hamburger 1988). The presence of mesectodermal cells in the ventral midline after mesoderm invagination has further raised the question as to whether these cells function in a way analogous to those of the vertebrate floor plate cells in the patterning of the nerve cord (Klambt et al. 1991; Yamada et al. 1991). To assess the influence of mesodermal and mesectodermal cells in the formation of the embryonic nervous system of Drosophila, we examined the number and position of neuroblasts in mutants without mesoderm and mesectoderm.

Formation of the mesoderm requires the zygotic gene activities of snail (sna) and twist (twi), whose expression in the ventral region is controlled by the maternal gene, dorsal (dl), the morphogen for the dorsal-ventral axis (Simpson 1983; Anderson 1987). Through the action of a group of maternal-effect genes, the dl protein becomes localized to the nuclei in the ventral region of the embryo; the concentration of nuclear $\mathrm{dl}$ protein is high in the presumptive mesoderm and drops sharply in the region flanking the mesodermal region (Roth et al. 1989; Rushlow et al. 1989; Steward 1989). The twi protein is found in cells that form the mesoderm and the adjacent mesectoderm (Thisse et al. 1988; Leptin and Grunewald 1990). Expression of sna, on the other hand, appears to be restricted to the presumptive mesoderm (Boulay et al. 1987; Leptin and Grunewald 1990). No mesodermal tissue forms in sna or twi mutants. Both sna, which has zinc-finger motifs, and twi, which contains a helix- 
loop-helix domain, are putative transcription factors (Boulay et al. 1987; Thiesse et al. 1988); they probably initiate mesodermal development by controlling gene expression.

We have determined both the late and early phenotypes of sna and twi mutants in the neuroectoderm and the mesectoderm. We found that the presence of neither the mesoderm nor the mesectoderm is necessary for the formation of neuroblasts, although the position of the neuroectoderm is shifted ventrally in the absence of mesoderm and mesectoderm. Cells that normally would form the mesoderm or the mesectoderm can take on the fate of neuroectodermal cells in these mutants. Our observations indicate that the positioning of the neuroectoderm depends on zygotic genes functioning in the mesoderm and mesectoderm; most of the mutant phenotypes can be accounted for by a testable hypothesis that involves cell-autonomous and cell-nonautonomous actions of these genes.

\section{Results}

Neuronal phenotype

In wild-type embryos, the neuroectoderm gives rise to both neuroblasts and epidermoblasts. Neuroblasts delaminate from the neuroectoderm, move into the space between the rest of the neuroectoderm and the invagi- nated mesodermal cells, and divide to produce neurons. Neurons from both sides of the embryo form the ventral nerve cord, which can be visualized immunocytochemically with $\mathrm{mAb} 44 \mathrm{Cl1}$, a monoclonal antibody that recognizes specifically the product of the elav gene in neuronal nuclei, or anti-HRP, a polyclonal antiserum that stains the neuronal membrane (Jan and Jan 1982; Bier et al. 1988). As shown in Figure 1, A-H, these antibodies revealed the formation of nerve cord in twi mutants and in sna twi double mutants, whereas the nervous system in sna mutants appeared to be deficient in the formation of the commissures and contained a gap between neurons on either side of the embryo. It is possible that some of the abnormalities revealed by these neuron-specific markers late during embryogenesis arose secondarily in a twisted embryo that failed to gastrulate properly. Nonetheless, the presence of ventral nerve cords in twi and sna twi mutants indicates that mesoderm is not required for the formation of the nerve cord.

To examine the effects of sna and twi mutations on early stages of neural development, prior to the appearance of neuron-specific markers, we looked at the pattern of neuroblasts that have just segregated from the epidermal layer by using an antiserum to the product of a gene in the $44 \mathrm{C}$ region of the second chromosome and an antiserum to the T8 product of the AS-C /E. Bier, $\mathrm{H}$. Vaessin, L.Y. Jan, and Y.N. Jan, in prep.; M. Brand, un-
Figure 1. Neural phenotype of sna and twi mutant embryos. $(A-D)$ Anti-elav staining of neuronal nuclei in stage 14 wild-type, $s n a^{I I G O 5}, t w i^{S 60}$, and $s n a^{\mathrm{IIGO5}} t w i^{\mathrm{S} 60}$ double mutants; $(E-H)$ anti-HRP staining of neuronal membranes in stage 14 embryos; $(I-L)$ anti-44C staining of neuroblasts in stage 9 embryos. Ventral views of embryos are shown. The anterior end is up.

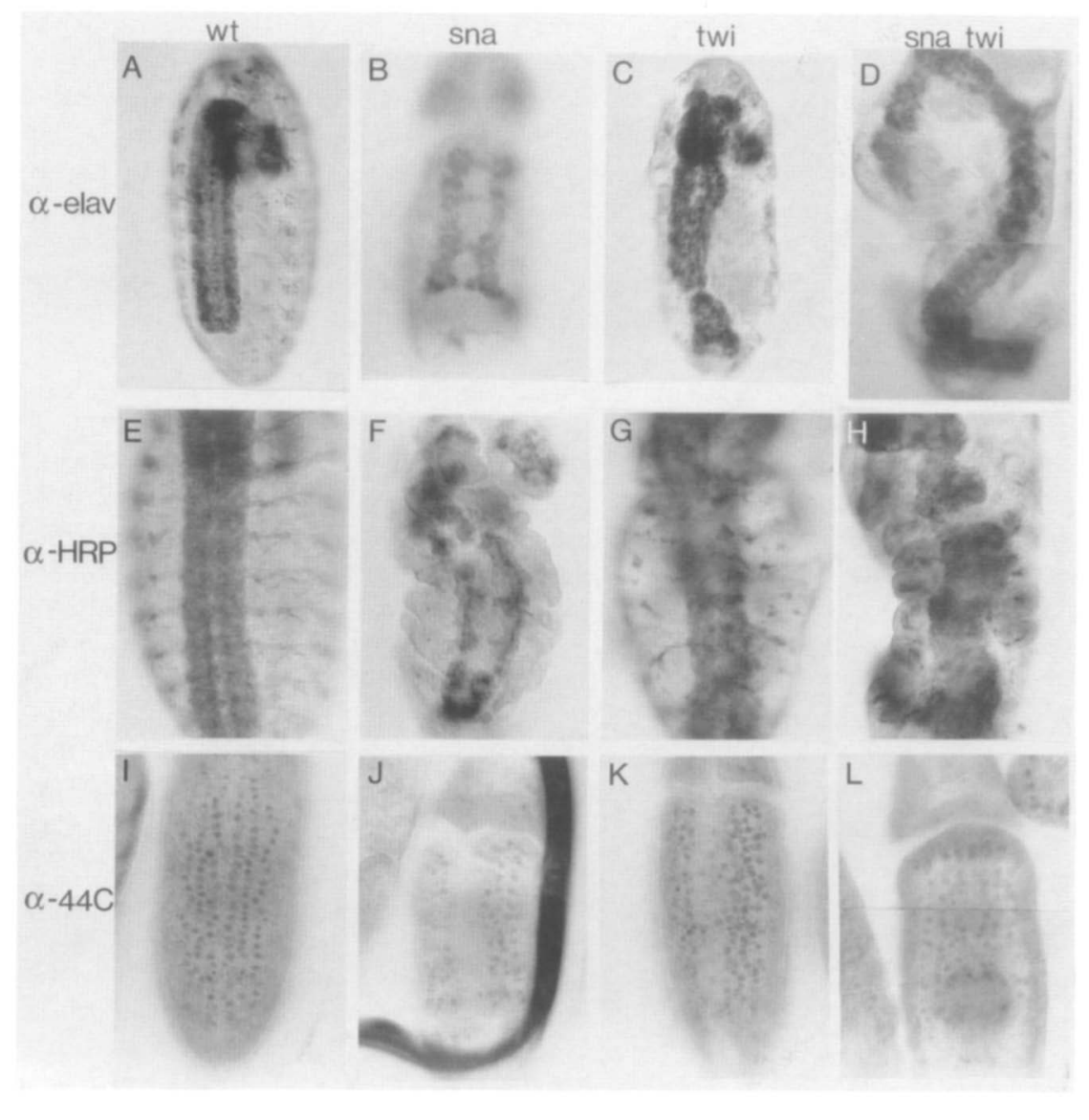


publ.). The number of neuroblasts per hemisegment in the cephalic and thoracic region of the stage 9 embryo was similar in the wild type $(14.4 \pm 1.6$; mean \pm S.D., average of 12 embryos), sna mutant $(14.8 \pm 1.8,9 \mathrm{em}$ bryos), twi mutant (14.2 $\pm 2,8$ embryos), and the sna twi double mutant (14.7 $\pm 1.5,10$ embryos) (see Materials and methods). There were, however, a few extra neuroblasts around the midline in twi or sna twi mutant embryos (Fig. 1I-L). Most of the neuroblasts were arranged roughly in three rows on either side of the embryo at stage 9, similar to the positions observed in the wild-type embryo (Fig. 1I-L). A ventral gap was evident between the neuroblast-containing regions on the two sides of the embryo in single mutants of sna or twi but not in sna twi double mutants, even though in both single mutants and double mutants cells in the ventral region fail to invaginate and form the mesoderm (Leptin and Grunewald 1990). Thus, although the number of neuroblasts was approximately normal in various mutants, the position of cells giving rise to neuroblasts appeared abnormal. This is examined more closely using markers for the proneural clusters, which appear early when the embryo still contains only a single layer of somatic cells.

\section{Ventral displacement of the neuroectoderm}

There are $\sim 100$ cells in the circumference of a cellular blastoderm. In normal embryo, the ventral-most 15-17 cells become mesodermal and invaginate, bringing the mesectodermal cells (one on either side) to the midline. At the end of ventral invagination, the mesectodermal cells also delaminate from the ectoderm to lie between the mesoderm and ectoderm. In sna and twi mutants, mesoderm is not formed and ventral cells fail to undergo normal invagination and often remain on the surface (Leptin and Grunewald 1990). A number of observations suggest that cells of the presumptive mesoderm do not die. First, the total number of cells in the mutants is the same as in the wild type (Leptin and Grunewald 1990). Second, the ventral cells show normal morphology and nuclear staining with antibodies (Leptin and Grunewald 1990), as well as expression of specific cytoplasmic RNAs (see below). Finally, mutant embryos stained with a dye for dying cells were indistinguishable from wildtype embryos at the early stages of development (B. Hay and Y. Rao, unpubl.). As shown below, the uninvaginated presumptive mesoderm domain in the mutants has been taken over partially or completely by the neuroectoderm.

$\mathrm{T} 5, \mathrm{~T} 4$, and T3 transcripts of AS-C are expressed initially in the proneural clusters that acquire the potential to become neural precursors (Cabrera et al. 1987; Romani et al. 1987). One or more cells in a proneural cluster will maintain the expression and go on to become a neural precursor. In the wild type, the distance between T5-staining cells on either side of the embryo is 17-20 cells. In sna or twi mutants, the distance between the neurogenic domains is reduced to $\sim 8-12$ cells (Fig. 2). In sna twi double mutants (Fig. 2D,H), there was no gap separating the neuroectoderm on either side of the em- bryo. Thus, the neuroectoderm shifted ventrally to take over part-or all, in the case of sna twi double mutantof the presumptive mesoderm domain. In the single mutants the ventral region that did not become neuroectoderm corresponded to the domain that would have formed the central mesoderm in wild-type embryos (Leptin and Grunewald 1990), whereas the region that would have become the peripheral mesoderm in wild-type embryos became the neuroectoderm.

\section{Ventrally displaced neuroectoderm requires proneural and neurogenic gene function}

Normal development of the nervous system is initiated with the expression of proneural genes such as those of the AS-C, which endows clusters of cells with the potential to become neuroblasts. In the absence of proneural gene function, some of the neuroblasts fail to appear (Dambly-Chaudiere and Ghysen 1987; Jimenez and Campos-Ortega 1990). Once a neuroblast has formed, it is thought to inhibit its neighboring cells from taking on the neuroblast fate (Doe and Goodman 1985). This process of lateral inhibition probably involves the function of zygotic neurogenic genes including $N, D 1$, Enhancer of split [E(spl)], neuralized (neu), big brain (bib), and mastermind (mam) (Lehmann et al. 1983; Wharton et al. 1985; Kidd et al. 1986; Knust et al. 1987; Vaessin et al. 1987; Artavanis-Tsakonas 1988; Kopczynski et al. 1988; Preiss et al. 1988; Yedbovnick et al. 1988; Rao et al. 1990; Boulianne et al. 1991; Heitzler and Simpson 1991). Loss of neurogenic gene activities leads to an overproduction of neuroblasts and neurons.

To determine whether the proneural genes and neurogenic genes also specify the formation of neuroblasts in sna and twi mutant embryos, we studied the expression patterns and the mutant phenotypes. As described above, the expression of proneural genes in AS-C was shifted ventrally. In addition, we found that $D I$ and $b i b$ were also expressed in more ventral regions in the mutants; these two neurogenic genes were normally expressed in mesectoderm, neuroectoderm, and more dorsal ectoderm but not in the mesoderm (Vaessin et al. 1987; Kopczynski et al. 1988; Haenlin et al. 1990; Rao et al. 1990). To test for the functional involvement of these genes, we looked at double mutants of $s n a$ and $s c^{B 57}$, $t w i$ and $s c^{B 57}$ or triple mutants of $s n a, t w i$, and $s c^{B 57}\left(s c^{B 57}\right.$ mutation is a deletion of the entire AS-C) and found that the nervous system was reduced (Fig. 3A-D). Loss of DI activity, on the other hand, led to overgrowth of the nervous system in sna, twi, or sna twi double mutants (Fig. 3E-H). Combinations of the sna or twi mutation with other neurogenic mutations such as $N, E(s p l)$, or neu also gave neurogenic phenotype (data not shown). Thus, both the proneural and neurogenic genes function in the ventrally displaced neuroectoderm.

\section{Mesectoderm and trachea formation in sna and twi mutants}

To examine the boundary of the neuroectoderm, we looked at the mesectoderm and tracheal pits, which are 
Figure 2. T5 expression in proneural clusters and neural precursors. $(A)$ Proneural clusters in a stage 6 wild-type embryo that has just begun ventral invagination; $(B-D)$ proneural clusters in stage 7 mutant embryos without any ventral invagination, showing that the proneural clusters on either side of the embryo are separated by a gap in sna $(B)$ or twi $|C|$ mutants, whereas they are contiguous in the double mutant $(D)$. Mutant embryos can be detected at stage 7 because ventral invagination would have been completed by this stage in the wild-type embryo. To examine the extent of separation of the proneural clusters on either side of the embryo, one may compare these mutant embryos with stage 6 wild-type embryos $(A)$, which have not yet undergone ventral invagination. $(E-H)$ T5 expression is restricted to one or a few neural precursors in late stage $8 \mathrm{em}$ bryos. In the wild-type embryo $(E)$, mesodermal and mesectodermal cells have invaginated and are thus no longer on the surface. In the double mutant $(H)$, the figure shown appears to reveal extra neuroblasts at the ventral midline, though the number of neuroblasts that express the gene at $44 \mathrm{C}$ is not much increased in the mutants (see text). $(I-L)$ Side views of late stage 8 embryos; the arrow points to invaginated mesoderm in the wild-type, which is absent in the mutant embryos.

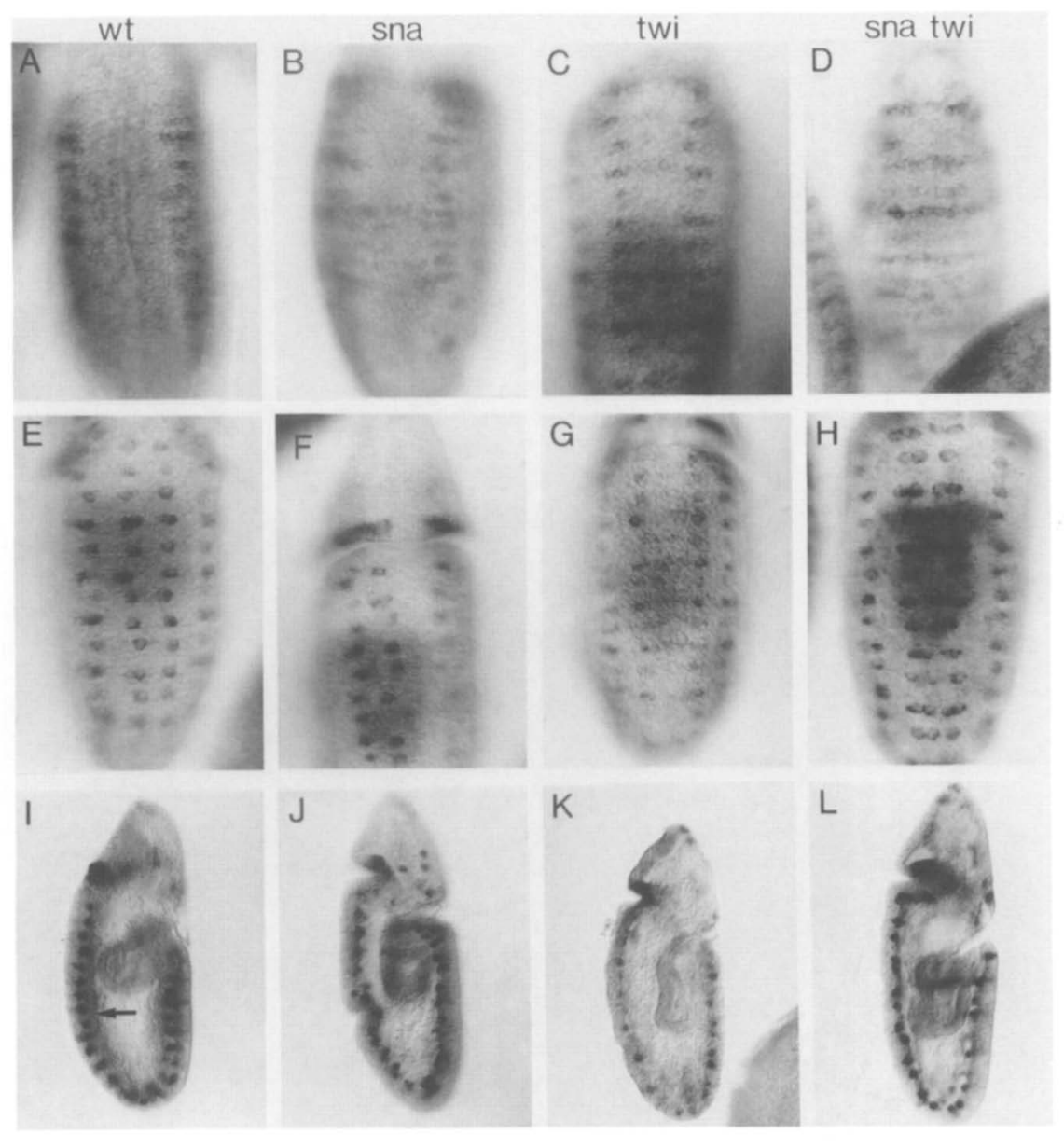

the immediate ventral and dorsal neighbors of the neuroectoderm, respectively (Campos-Ortega and Hartenstein 1985). The mesectodermal cells can be examined with the expression pattern of the rhomboid (rho) gene and the $\mathrm{m} 7$ gene of the $E(s p l)$ locus (Knust et al. 1987; Bier et al. 1990). rho is initially expressed in stripes of eight cells flanking the mesoderm in a cellularizing embryo. This pattern is then modulated segmentally so that the medial-most row is rho positive in all the segments, whereas there are additional ectodermal cells expressing rho in every other segment (Fig. 4D). The expression in all segments becomes restricted to this medial-most row of cells, the mesectodermal cells, on either side of the embryo, just before the beginning of gastrulation and remains in these cells thereafter. In addition, rho is expressed in the tracheal pits during germ-band extension (Bier et al. 1990). m7, on the other hand, is initially expressed in stripes of about four cells on either side of the embryo and then becomes restricted to the medial-most row on either side of the embryo before the completion of cellularization (Fig. 4A) (Knust et al. 1987). The medial-most rows of rho-expressing cells and $\mathrm{m} 7$-expressing cells were identified as the mesectodermal cells because these cells were brought to the ventral midline as the mesoderm invaginated, and they subsequently delaminated to lie between the ectoderm and the mesoderm.
The maintained expression of rho in mesectodermal cells in germ-band-extended embryos revealed further that the rho-expressing ventral midline cells are the same cells that would express another mesectodermal marker, single-minded (sim) (Nambu et al. 1990).

Previous studies have shown that the number of cells expressing sim was increased in sna mutants in germband-extended embryos (Leptin and Grunewald 1990; $\mathrm{Nambu}$ et al. 1990). Consistent with these findings in late embryos, we found an increased number of rho-expressing cells in sna mutants (Fig. 4G). In twi mutants, there were several rho-expressing cells flanking a stripe of nonexpressing cells (Fig. $4 \mathrm{H}$ ). In the double mutant, no rho-expressing cells were detected at the ventral midline, although rho was still expressed in the tracheal pits (Fig. 4I). Thus, both the sim expression pattern shown in previous studies and the rho pattern in germ-band-extended embryos revealed an expansion of mesectodermal cells in sna mutants, whereas no mesectodermal cells were found in the double mutant.

To examine the early steps in mesectodermal formation, we looked at $\mathrm{m} 7$ and $r$ ho expression in cellularizing (stage 5) and gastrulating (stage 6) embryos. In sna mutants, $\mathrm{m} 7$ expression was detected initially in the ventral region of the cellular blastoderm $(\sim 17-19$ cells); the central 10-12 cells showed stronger expression than the pe- 


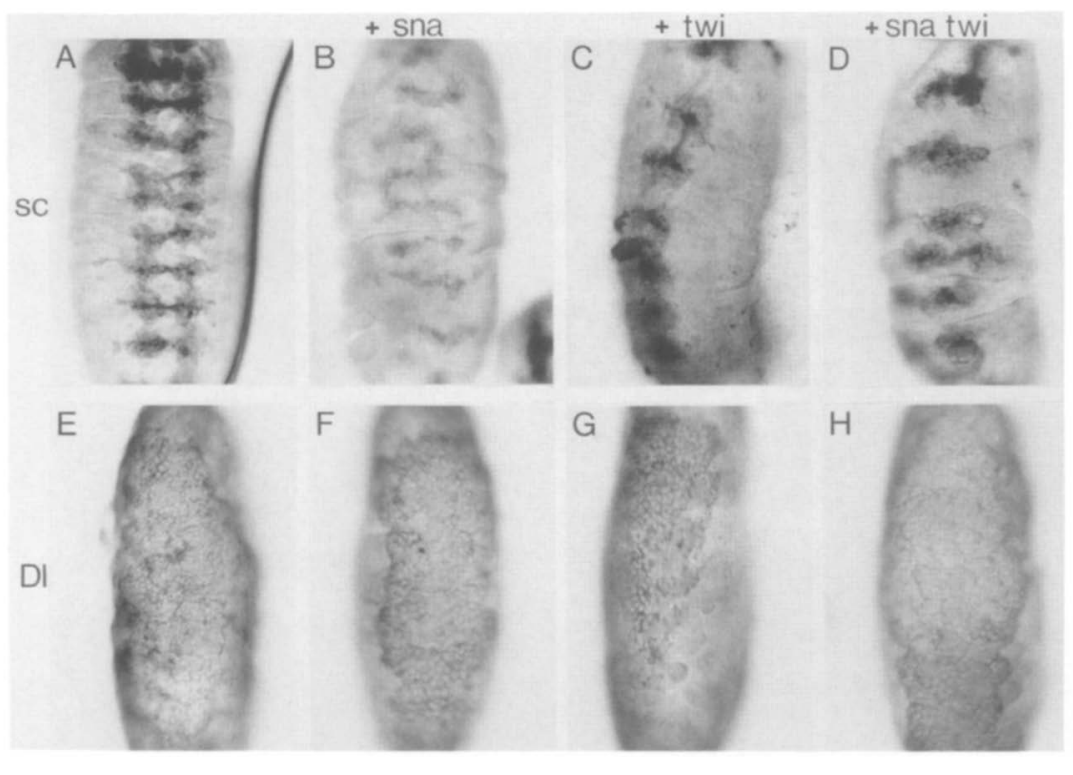

Figure 3. Dependence of the ventrally shifted neuroectoderm on the function of the proneural and neurogenic genes. $(A-D)$ Reduced nervous systems in stage 14 embryos as revealed by anti-HRP staining of $s c^{B 57}$ single mutant $(A) ; s c^{B 57} s n a^{I I G 05}(B)$ and $s c^{B 57} t w i^{S 6 O}(C)$ double mutants; or $s c^{B 57} s n a^{I I G O 5} t w i{ }^{S 60}$ triple mutants $(D) .(E-H)$ Hyperplasia of neural tissue as revealed by anti-HRP staining of $D l^{9 P 39}(E)$, $D 1^{9 P 39}$ sna $^{I I G 05}(F)$ and $D 1^{9 P 39} \mathrm{twi}^{\mathrm{S} 60}(G)$ double mutants; or $D l^{9 P 39}$ sna $^{I I G O 5} \mathrm{twi}^{\mathrm{S} 60}$ triple mutants $(H)$. ripheral cells (Fig. 4B). The expression was then limited to the central 10-12 cells around the beginning of stage 6. In twi mutants, flanking the ventral region of cells that did not express $m 7(6-10$ cells $)$, there were $2-4 \mathrm{~m} 7$ expressing cells on either side of a stage 5 embryo, as compared to 1-3 m7-expressing cells on either side of a stage 6 embryo (Fig. 4C). Although this 6- to 10-cell-wide ventral stripe showed no $\mathrm{m} 7$ expression at stage 5 , some of the cells did express $\mathrm{m} 7$ at stage 6 (Fig. 4C). In sna twi double mutants, no mesectodermal cells were detected in stage 5 or stage 6 embryos; the two longitudinal rows of rho-expressing cells were absent in a late stage 5 wildtype embryo even though rho expression was detectable in ectodermal cells that extended from one side of the embryo to the other side (Fig. 4E). The absence of $\mathrm{m} 7$ staining was also confirmed by in situ hybridization with both $\mathrm{m} 7$ and $\mathrm{T} 5$ probes, which showed an expression pattern of only $\mathrm{T} 5$ but not $\mathrm{m} 7$ in sna twi double mutants (data not shown).

The dorsal limit of the neuroectoderm, the tracheal pits, could be identified by their rho expression (Bier et al. 1990). The relative positions of the neuroectoderm and the tracheal pits as revealed by double staining with the anti-44C antibody for neuroblasts and the rho cDNA probe for the tracheal pits were not altered in the mutants (Fig. 5A-D). Thus, the dorsal limit of the neuroectoderm was also shifted ventrally. In other words, the mutant phenotype was characterized mainly by a ventral shift of the neuroectoderm because of changes of cell fate. How the dorsal-most region of the embryo is altered remains to be determined.

\section{Summary of cell fate transformation in sna and twi mutant embryos}

The observed changes of cell fate are summarized in Figure 6 and schematically illustrated in Figure 7. In either single or double mutants of sna and twi, the ventral- most cells fail to form mesoderm. In sna mutants, cells in the presumptive central mesoderm domain take on the fate of mesectodermal cells, whereas cells in the presumptive peripheral mesoderm domain take on the fate of neuroectoderm. In twi mutants, cells in the presumptive peripheral mesoderm domain again become neuroectodermal cells, whereas cells in the presumptive central mesoderm domain are divided into three types: Some have become mesectodermal cells, some have become neuroblasts (Fig. 8D), and the others are neither. In sna twi double mutants, neither mesoderm nor mesectoderm is formed; rather, the neuroectoderm has moved into the ventral most region.

\section{Neuroectoderm positioning is relatively independent of the nuclear concentration of dl protein}

The ventral shift of neuroectoderm and mesectoderm in sn $a$ and $t$ wi mutants could either result directly from the impairment of zygotic gene activities of sna and twi or be a secondary effect because of the effects of sna and $t w i$ mutations on dl concentration. Because dl nuclear localization is controlled by a group of maternal-effect genes prior to the expression of sna and $t w i$, the establishment of a dl gradient does not require sna or twi. To examine the possible roles of sna and twi in the maintenance of $\mathrm{dl}$ gradient, we looked at the distribution of $\mathrm{dl}$ in sna and twi mutants. In wild-type embryos, $\mathrm{dl}$ is localized to the nuclei of the mesodermal and mesectodermal cells but is not detectable in the nuclei of the neuroectodermal cells (Roth et al. 1989; Steward 1989). The level of dl protein is higher at the cellular blastoderm stage than at the gastrulation stage (Fig. 8A,B). Nuclear dl protein was also found in the mutants at the earliest stage (gastrulation) when mutant embryos could be identified (Fig. 8C). Although it was difficult to determine quantitatively whether the level of $\mathrm{dl}$ was different between the wild type and the mutants, there was $\mathrm{dl}$ protein in the nuclei 

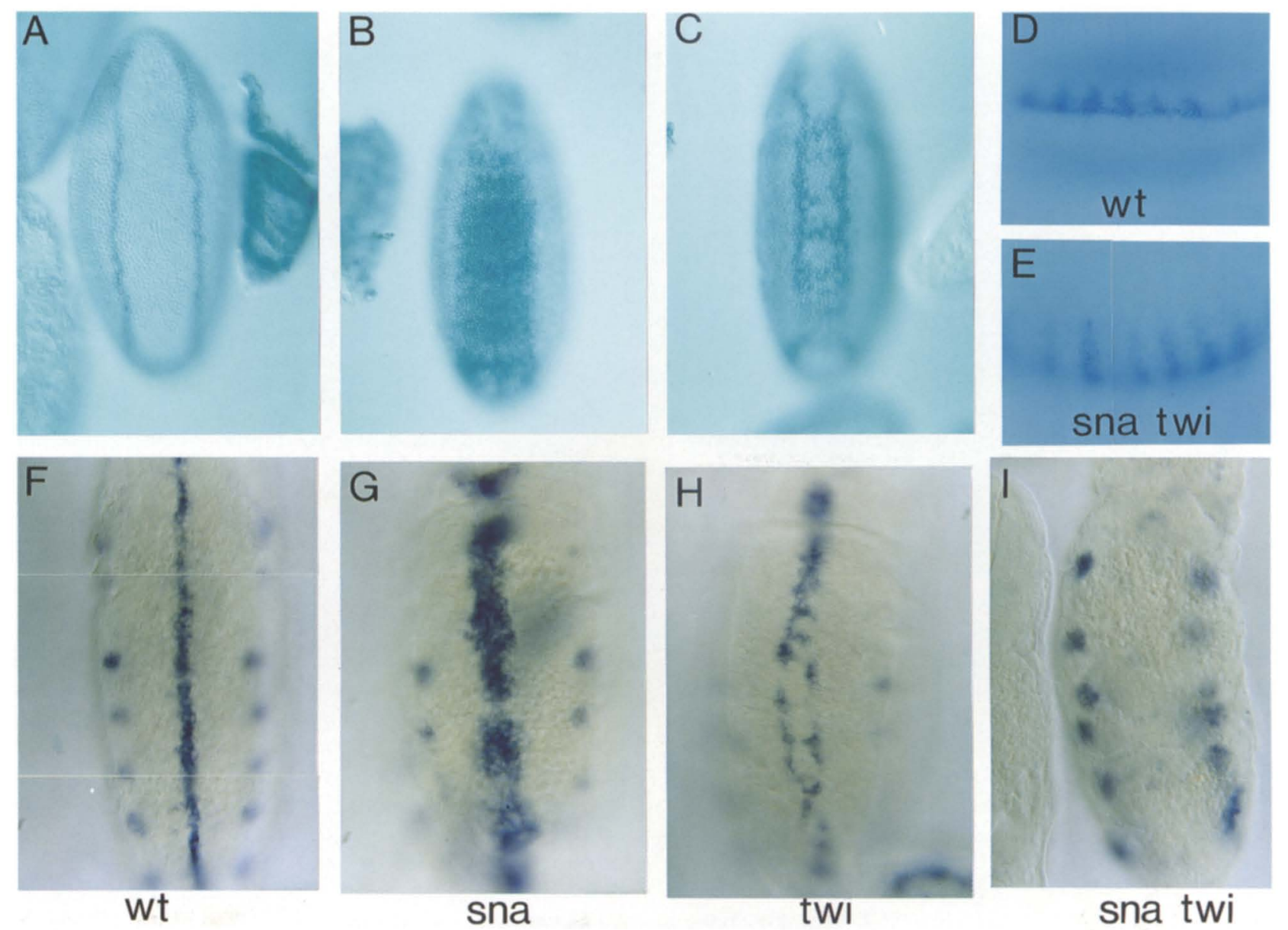

Figure 4. Mesectoderm formation. $(A-C) \mathrm{m} 7$ expression in stage 5 wild-type $|A|$ and sna $(B)$ embryos and a stage 6 twi embryo $(C)$; the weaker staining of the more peripheral cells in sna mutants disappears by stage 6 leaving $8-12 \mathrm{~m} 7$-expressing cells; the $\mathrm{m} 7$ expression pattern in $t w i$ mutants at stage 5 is similar to that in the stage 6 embryo shown here except that there are no $\mathrm{m} 7$-expressing cells in the ventral-most region between the two longitudinal rows. The ventral side of embryo is shown; anterior is to the top. $(D-E)$ rho expression in cellular blastoderms of wild-type and sna twi double mutant. In the wild type $(D)$, rho is expressed in certain ectodermal cells in every other segment as well as the mesectodermal cells in all segments. In the sna twi double mutant $(E)$, there is no mesectodermal expression of rho even though rho is still expressed in the ectodermal cells that extend from one side of the embryo to the other. Anterior is to the left; dorsal is up. $(F-I)$ rho expression in germ band-extended embryos. Both the midline cells (mesectodermal derivatives) and the tracheal pits express rho.

of cells in the ventral region of the sna twi double mutants (Fig. 8C). The fact that these cells took on the neuroectodermal fate indicates that this switch of cell fate did not arise because the nuclear dl concentration in sna twi double mutants was reduced to the nondetectable level normally found in neuroectodermal cells. Moreover, in twi mutants, the presence of several ventral neuroblasts surrounded by rho-expressing mesectodermal cells (Fig. 8D; note also a few T5-staining cells in the ventral midline in Fig. $2 \mathrm{C}$ and one neuroblast surrounded by mesectodermal cells in Fig. $5 \mathrm{Cl}$ presents a pattern that is unlikely to arise if the effect of the twi mutation is simply to change the dl gradient or the threshold concentration of nuclear $\mathrm{dl}$ required to suppress neuroectoderm formation. Taken together, these observations suggest that loss of zygotic gene activity of sna and twi alters the fate that a cell adopts at blasto- derm without significantly changing the dorsoventral positional value of that cell.

\section{Discussion}

Our analyses of cell fate specification in mutants lacking the zygotic gene activities of sna and twi have implications concerning both neuroectoderm and mesectoderm formation. In the case of mesectoderm, no transcriptional regulators have been shown previously to be essential in the early steps of mesectoderm determination (Bier et al. 1990; Nambu et al. 1990; Klambt et al. 1991), although putative transcription factors have been identified for the determination of the other domains around the circumference of the embryo (Doyle et al. 1986, 1989; Boulay et al. 1987; Villares and Cabrera 1987; Thisse et al. 1988; Gonzalez et al. 1989; Jimenez and 

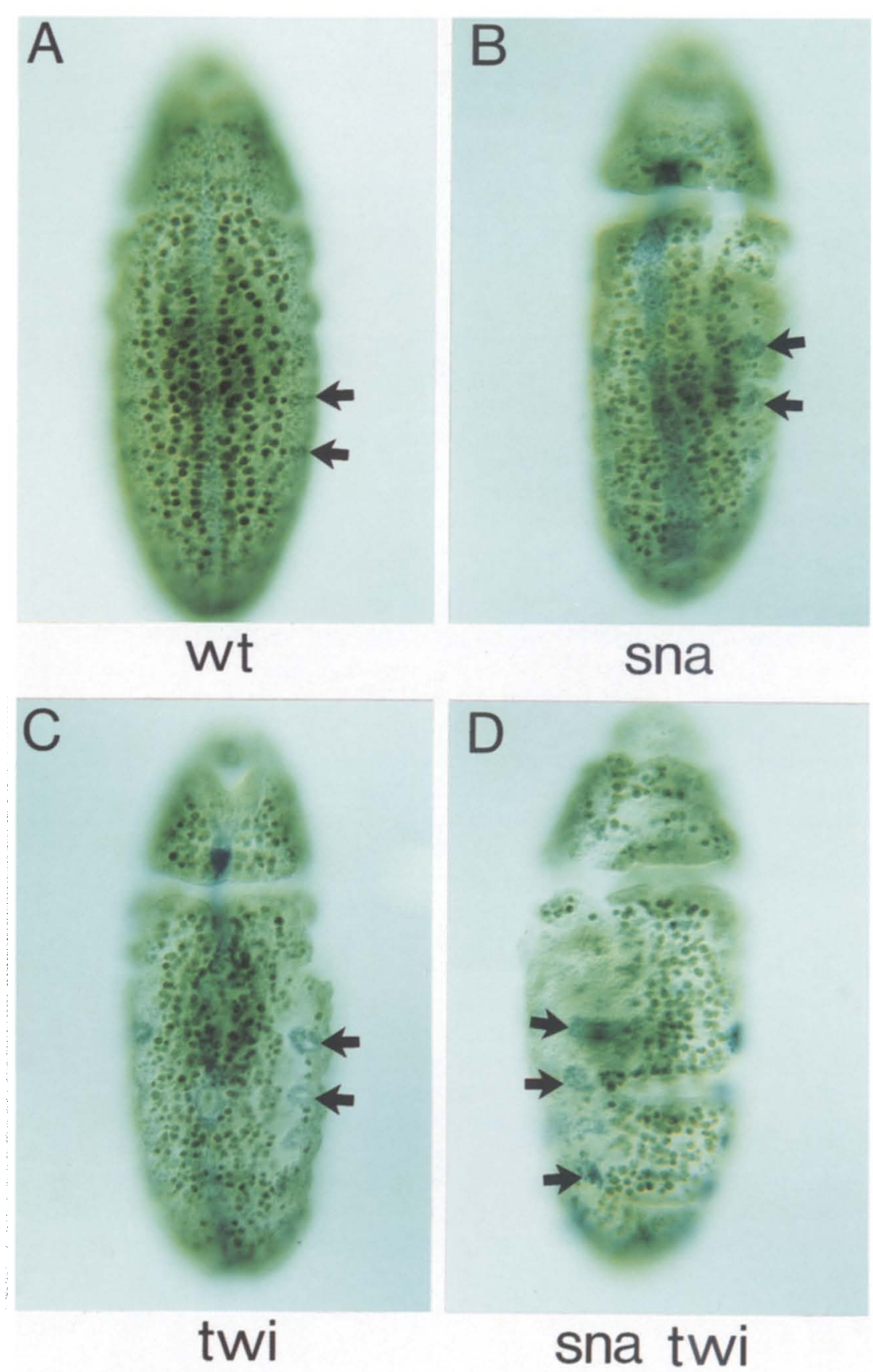

Figure 5. Position of the neuroectoderm relative to tracheal pits and the ventral midline cells. $(A-D)$ Double-labeling with an anti-44C antibody specific for neuroblasts and a rho DNA probe that labels the tracheal pits as well as midline cells. The three rows of brown dots are neuroblasts; the blue lines at the ventral midline are mesectodermal cells. The blue circles marked by arrows at the lateral sides of the embryos are the tracheal pits. The relative positions of tracheal pits and the lateral row of neuroblasts appear similar in the mutants $(B-D)$ and the wild type $(A)$. Note that there is a neuroblast surrounded by rho-expressing cells in the twi mutant embryo $(C)$.
Campos-Ortega 1990|. The finding of the absence of the earliest signs of mesectodermal formation in sna twi double mutants therefore suggests that these two genes are involved in mesectoderm determination.

\section{Specification and positioning of the neuroectoderm}

By following the formation of the nervous system in $\mathrm{mu}-$ tants without mesoderm, we reached the following conclusions concerning neural development in Drosophila embryos.

We have shown that neither mesodermal nor mesec- todermal cells are essential for neuroblast formation, because neuroblasts were found in embryos lacking mesoderm or both mesoderm and mesectoderm, as in sna twi double mutants. Although neural induction in vertebrates has been studied for decades (Spemann 1938; Hamburger 1988), the limited accessibility of Drosophila embryos to surgical manipulation has made it difficult to assess the potential role of the mesoderm in neural development. In an earlier experiment, in which the dorsal-ventral axis was changed by altering the activity of the $\mathrm{d} l$ morphogen, neural tissue could be detected in certain $d l$ mutants in the apparent absence of mesodermal derivatives (Campos-Ortega 1983). At that time, though, 
Figure 6. Summary of the estimated numbers of cells in the mesoderm, mesectoderm, and neuroectoderm domains. Mesoderm, which corresponds to the ventralmost 15-17 cells in the wild-type embryo, is absent in single or double mutants of sna and twi (Simpson 1983; Leptin and Grunewald 1990). Mesectoderm formation takes place at late stage 5 and can be recognized by the expression of $\mathrm{m} 7$. The neuroectoderm is identified by the early expression of $\mathrm{T} 5$ in proneural clusters. Numbers in the boxes are the number of cells along the circumference of an embryo

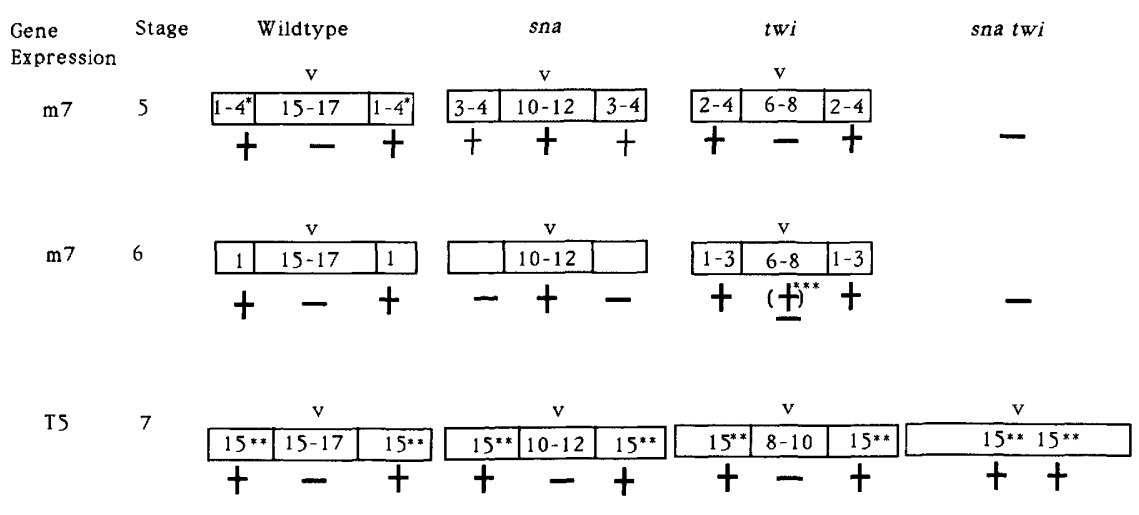
staining for a certain marker. $|+|$ Staining $(-)$ no staining; ( $\mathrm{v}$ ) ventral midline. $\left(^{*}\right)$ The width of $\mathrm{m} 7$-staining stripes changes from about four cells in early stage 5 to one cell in late stage $5 ;\left(^{* *}\right)$ the width of neuroectoderm is $\sim 15$ cells at stage 5 and stage 7 ; T5 is expressed in a ventral proneural cluster of $3-5$ cells wide, which is separated from a lateral T5-expressing proneural cluster of $\sim 5$ cells wide by $\sim 5$ cells that do not express $\mathrm{T} 5$. ${ }^{\star \star \star}$ ) In $t$ wi mutants, some of the ventral-most cells express $\mathrm{m} 7$, whereas others do not (see Fig. $4 \mathrm{C}$ ).

the absence of early markers precluded the possibility of detecting early mesoderm and neuroectoderm, making it difficult to rule out the possibility that there was a small amount of mesoderm or a transient existence of mesoderm at the early stages of embryogenesis or to assess the overall effect of changing the dorsal-ventral axis. In this study, the dorsal-ventral gradient, as defined by the $\mathrm{dl}$ morphogen, is probably not altered by mutations of the zygotic genes required for mesoderm formation, and the use of multiple early markers has made it possible to show that the mesoderm and mesectoderm are not required for neural induction. It remains possible, however, that mesodermal or mesectodermal derivatives are involved in later processes of neural development, such as axonal guidance (Klambt et al. 1991). It is worth noting that in the vertebrates, although the mesoderm is shown to be able to induce the formation of neural tissue on transplantation (Spemann 1938; Hamburger 1988), most of the experiments did not resolve the question of the normal role of mesoderm in neural development. Recent experiments in Xenopus embryos have shown that some neural-specific markers could be induced even when mesoderm invagination was prevented (Kintner and Melton 1987; Dixon and Kintner 1989; Jones and
Woodland 1989; Ruiz i Altaba 1990; see also Sharpe et al. 1987; Hemmati-Brivanlou and Harland 1989|. It has also been observed in some cases that neural tissue could form without detectable mesodermal structures /Green and Smith 1990; Godsave and Slack 1991). In none of these situations, however, could the role of mesoderm in neural induction in vertebrates be excluded.

With regard to the positioning of the neuroectoderm in Drosophila embryos, we found that the neuroectoderm is shifted ventrally in sna, twi, and sna twi double mutants, even though these mutants do not show any obvious alterations in the distribution of the morphogen $\mathrm{dl}$ or any cell death. Thus, ventral cells that have positional values of mesodermal cells in wild-type embryos can adopt neuroectodermal cell fates in the absence of zygotic gene activity of $t w i$, sna, or both.

Concerning the size of the neuroectoderm, we found that the number of neuroectodermal cells appeared fairly constant even though these cells were at different locations along the dorsal-ventral axis and in rather different surroundings. Thus, the control of the size of the neuroectoderm appears to be intrinsic to the developmental program of the neuroectodermal cells and rather independent of their ventral neighbors or their dorsal-ventral
Figure 7. Summary of cell fate changes in sna and twi mutants. The relative positions of mesoderm, mesectoderm, neuroectoderm, and tracheal pits are shown in the diagram. The tracheal anlagen are indicated by broken lines (in small circles) because it is not known whether the tracheal pits are determined in the cellular blastoderm or at later stages. In the fate map the tracheal anlagen is positioned just dorsal to the neuroectoderm (Campos-Ortega and Hartenstein 1985). "Unspecified" in twi mutants refers to cells that do not express several transcripts or proteins specific for mesectodermal or neuroectodermal cells.

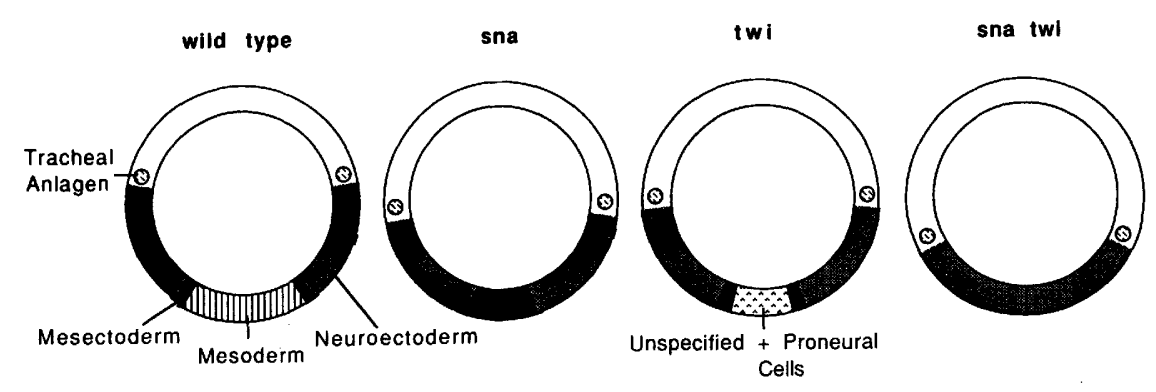



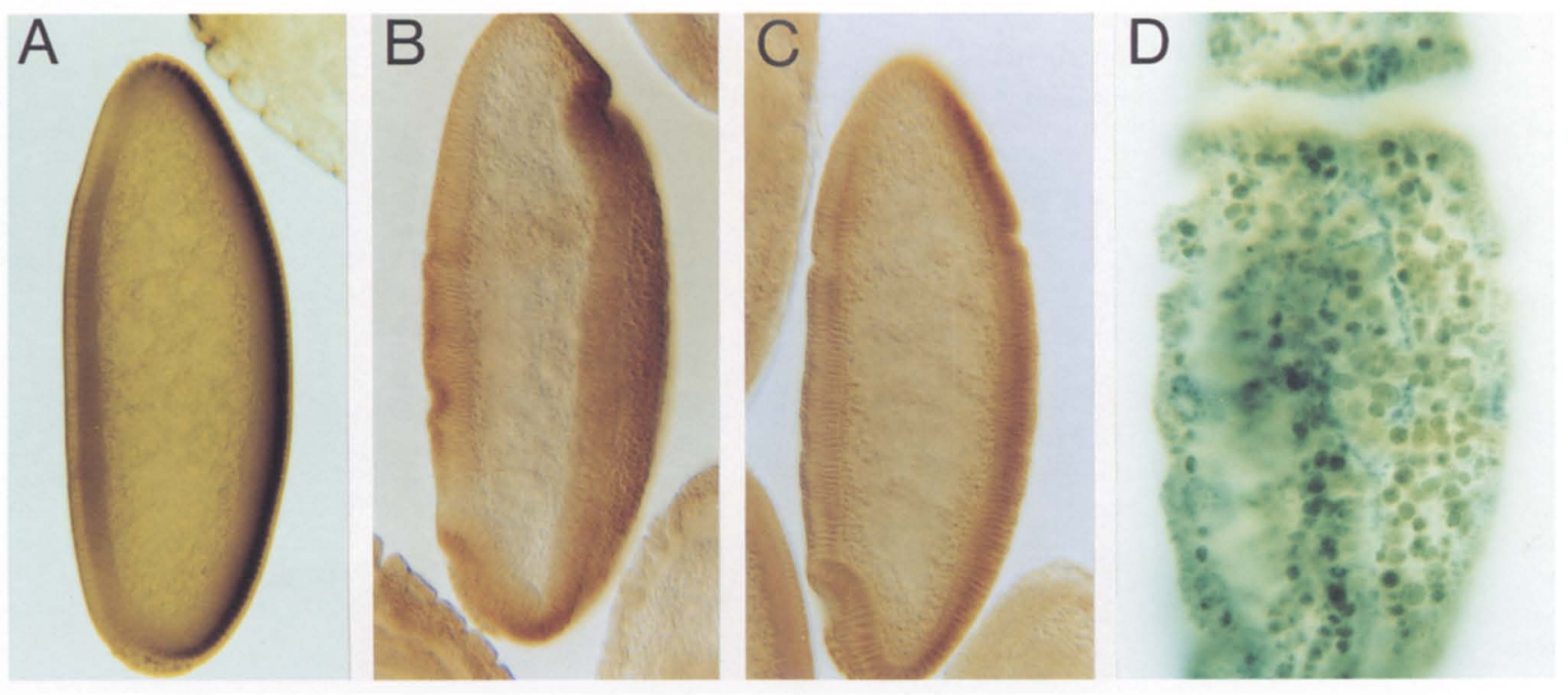

Figure 8. Positioning of neuroectoderm is not directly correlated with dl nuclear localization. (A) Anti-dl staining in a wild-type cellularizing embryo; $(B)$ anti-dl staining in a stage 6 wild-type gastrulating embryo showing a decreased level of nuclear staining in the invaginating cells; $(C)$ anti-dl staining of ventral nuclei in a stage 6 sna twi double mutant embryo that shows no ventral invagination. $(A-C)$ Anterior is to the top; ventral is to the right. $(D)$ The ventral view of a twi mutant embryo labeled with the anti-44C antiserum for neuroblasts and the rho DNA probe showing that neuroblasts around the ventral midline are flanked on either side by rho-expressing mesectodermal cells.

positional values. It remains to be determined whether the dorsal neighbors of neuroectoderm exert any influence in defining the dorsal limit of the neuroectoderm.

\section{A model for cell fate specification in the ventral region of Drosophila embryos}

The removal of mesoderm in sna or twi mutants results in a ventral shift of both neuroectoderm and mesectoderm, whereas in the double mutant no mesectoderm forms and the neuroectoderm is located in the ventralmost region. Moreover, the ventral-most cells take on mesectodermal cell fate in sna mutants, but some of them appear unspecified in twi mutants. To explain the results obtained by us and others thus far (for summary, see Fig. 7; see also Leptin and Grunewald 1990; Nambu et al. 1990), we propose a testable model: (1) Mesoderm formation requires both sna and $t w i$ function within mesodermal cells, and these two genes act in combination, not strictly in a sequential manner, as shown previously (Simpson 1983; Leptin and Grunewald 1990); (2) mesectodermal formation requires either twi expression in the mesectodermal cells or sna activity in adjacent cells, but is suppressed by sna activity within the cell; and (3) the neuroectodermal cell fate is suppressed by sna activity within the cell or by the commitment of a cell to the mesectodermal fate.

This model is consistent with the observed expression patterns of sna and twi and with the mutant phenotypes: The reported distribution of $t w i$ is wider than that of sna, which is restricted to the mesoderm (Thisse et al. 1988;
Leptin and Grunewald 1990). We confirmed with double labeling that twi is expressed in mesectodermal cells (data not shown). Thus, in the wild-type embryo, ventral cells that express both sna and twi form the mesoderm, whereas their immediate neighbors that express twi but not sna form the mesectoderm; neither of these two groups of cells form the neuroectoderm. In sna mutants, the ventral cells that express twi become mesectodermal cells and their neighbors form the neuroectoderm. In twi mutants, the ventral cells that express sna do not take on the fate of mesoderm, mesectoderm, or neuroectoderm, whereas their immediate neighbors form the mesectoderm. In sna twi double mutants, the ventral cells do not express either gene and therefore will not form mesoderm or mesectoderm; they take on the default fate of neuroectoderm.

A number of predictions may be tested to determine the validity of the proposed model: (1) A variety of double-labeling experiments should determine whether the basic assumption of the correlation between the expression patterns of sna and twi and the various cell fates is correct; (2) ectopic expression of sna and twi may test further the causal relation between sna and twi expression and cell fate; and (3) our proposal that mesectodermal formation in twi mutants results from sna activity in neighboring cells predicts that sna distribution is limited to the presumptive central mesoderm in twi mutants, which is flanked by mesectodermal cells. We note that these predictions are all qualitative and apply only to the early expression patterns at a stage relevant for these cell fate determination events. It is quite possible 
that future studies will reveal deviations from the predictions of this simple model. Experiments such as those outlined here should nevertheless help further our understanding of cell fate specification during early embryogenesis.

Since the submission of this paper, Alberga et al. (1991) have reported the expression pattern of sna RNA and protein. The sna protein is expressed first in the primordium of the anterior midgut and in the mesoderm; expression of sna in mesectodermal cells and neuroectodermal cells appears much later, probably after the stages when they express specific early markers. Moreover, sna expression in twi mutant embryos at the blastoderm stage is more restricted, in a ventral stripe that is approximately the width of the presumptive central mesoderm. These observations are in accord with our model, although double-labeling experiments are necessary to examine its predictions with better spatial and temporal resolution.

\section{Materials and methods}

\section{Drosophila strains}

The alleles used, sna $a^{I I G O S}, t w i^{\mathrm{S} 60}$, and $s n a^{I I G O 5} t w i^{\mathrm{S} 60}$ recombinant, are the same amorphic alleles that were characterized in detail for their mesoderm formation defects (Leptin and Grunewald 1990). The $s c^{B 57}$ mutation is a deletion of the entire AS-C (isolated by E. Grell; Gonzalez et al. 1989). $D I^{9 P 39}, N^{55 e 11}$, and $E(s p 1)^{8 D 06}$ are amorphic alleles of the neurogenic genes (Lehmann et al. 1983; Ziemer et al. 1988). Double mutants of a mesodermal gene and a proneural gene or a neurogenic gene are easily recognizable because the sna or twi mutation causes characteristic twisting of the embryo, whereas the other mutations cause reduction or overproduction of the nervous tissue. Staging of mutant embryos was done with the same criteria (except that mutants do not form the ventral furrow) as for the wild-type embryos (Campos-Ortega and Hartenstein 1985); stage 6 and 7 embryos are staged according to the appearance of pole cells and the cephalic furrow, and stage 8 and 9 embryos are staged according to the extent of the germ-band extension.

\section{Immunocytochemistry}

Embryos of appropriate stages were collected on grape plates. They were dechorionated with $50 \%$ bleach for several minutes and rinsed in water before fixation for $20 \mathrm{~min}$ in $4 \%$ formaldehyde in PBS (covered with heptane) and removal of the vitelline membrane in methanol. Embryos can be stored in ethanol at $-20^{\circ} \mathrm{C}$ for months before antibody staining (Bodmer et al. 1987) or in situ hybridization.

To obtain a quantitative measure of the number of neuroblasts per segment, we first made sure that the number of transverse rows of neuroblasts was the same in the cephalic and thoracic region of the wild-type and mutant embryos and then measured the total number of neuroblasts that expressed the gene at $44 \mathrm{C}$ so as to obtain an average number per segment (four transverse rows; see Campos-Ortega and Hartenstein 1985). In twi mutants, the isolated neuroblasts in the presumptive central mesoderm region were not included in the neuroblast count. In the sna twi double mutants, however, the neuroblasts in the ventral midline were included in the cell count.
In situ hybridization

The in situ hybridization protocol that we used was modified from Tautz and Pfeifle (1989). Probes were prepared with a Boehringer Mannheim kit according to manufacturer's protocol with the modifications that $5 \mu \mathrm{g}$ of random primers was added in the labeling reaction and that reaction was allowed to go on overnight. Products from one labeling reaction with $<1 \mu \mathrm{g}$ of template DNA were stored in $30 \mu \mathrm{l}$ of water at $-20^{\circ} \mathrm{C}$, from which $3 \mu l$ was used for each hybridization.

\section{Double staining with an antibody and a DNA probe}

The embryos were first stained with an antibody and then processed for in situ hybridization. Immunocytochemistry was performed according to the protocol described previously (Bodmer et al. 1987) to the step after diaminobenzidine (DAB) reaction. Stained embryos dehydrated in ethanol were then used for in situ hybridization in the same way as described above. Color development was monitored closely to maximize the detection of both signals.

\section{Acknowledgments}

We thank S. Barbel for excellent technical assistance; K. Anderson for $s n a$ and twi mutants; E. Grell for $s c^{B 57}$; E. Bier for the rho probe; J. Modolell for AS-C probes; E. Knust for the $\mathrm{m} 7$ probe; $\mathrm{R}$. Steward, D. Stein, and C. Nüsslein-Volhard for anti-dl antisera; L. Ackerman for help with photography; R. Carretto for help with embryo collections; K. Prewitt for manuscript preparation; J.Y. Wu for helpful discussions; and V. Siegel for helpful comments on the manuscript. Y.R. was supported by the Neuroscience Program at the University of California at San Francisco. L.Y.J and Y.N.J. are Howard Hughes Medical Institute investigators.

The publication costs of this article were defrayed in part by payment of page charges. This article must therefore be hereby marked "advertisement" in accordance with 18 USC section 1734 solely to indicate this fact.

\section{References}

Alberga, A., J.L. Boulay, E. Kempe, C. Dennefeld, and M. Haenlin. 1991. The snail gene required for mesoderm formation in Drosophila is expressed dynamically in derivatives of all three germ layers. Development 111: 983-992.

Anderson, K. 1987. Dorsal-ventral embryonic pattern genes of Drosophila. Trends Genet. 3: 91-97.

Artavanis-Tsakonas, S. 1988. The molecular biology of the Notch locus and the fine tuning of differentiation in Drosophila. Trends Genet. 4: 95-100.

Bier, E., L. Ackerman, S. Barbel, L. Jan, and Y.N. Jan. 1988. Identification and characterization of a neuron-specific nuclear antigen in Drosophila. Science 240: 913-916.

Bier, E., L.Y. Jan, and Y.N. Jan. 1990. rhomboid, a gene required for dorso-ventral axis establishment and peripheral nervous system development in Drosophila melanogaster. Genes \& Dev. 4: 190-203.

Bodmer, R., S. Barbel, S. Shepherd, J.W. Jack, L.Y. Jan, and Y.N. Jan. 1987. Transformation of sensory organs by mutations of the cut locus of D. melanogaster. Cell 51: 293-307.

Boulay, J.L., C. Dennefeld, and A. Alberga. 1987. The Drosophila developmental gene snail encodes a protein with nucleic acid binding fingers. Nature 330: 395-398.

Boulianne, G.L., A. de la Concha, J.A. Campos-Ortega, L.Y. Jan, and Y.N. Jan. 1991. The Drosophila neurogenic gene neural- 
ized encodes a novel protein which is expressed in precursors of larval and adult neurons. EMBO $\%$. (in press).

Cabrera, C.V., A. Martinez-Arias, and M. Bate. 1987. The expression of three members of the achaete-scute gene complex correlates with neuroblast segregation in Drosophila. Cell 50: 425-433.

Campos-Ortega, J.A. 1983. Topological specificity of phenotype expression of neurogenic mutations in Drosophila. Wilhelm Roux's Arch. Dev. Biol. 192: 317-326.

Campos-Ortega, J.A. and V. Hartenstein. 1985. The embryonic development of Drosophila melanogaster. Springer Verlag, Heidelberg.

Campos-Ortega, J.A. and Y.N. Jan. 1991. Genetic and molecular bases of neurogenesis in Drosophila melanogaster. Annu. Rev. Neurosci. 14: 399-420.

Campuzano, S., L. Carramolina, C.V. Cabrera, M. Ruiz-Gomez, R. Villares, A. Boronat, and J. Modolell. 1985. Molecular genetics of the achaete-scute gene complex of Drosophila melanogaster. Cell 40: 327-338.

Caudy, M., H. Vaessin, M. Brand, R. Tuma, L.Y. Jan, and Y.N. Jan. 1988. daughterless, a Drosophila gene essential for both neurogenesis and sex determination, has sequence similarities to myc and the achaete-scute complex. Cell 55: 10611067.

Dambly-Chaudiere, C. and A. Ghysen. 1987. Independent subpatterns of sense organs require independent genes of the achaete-scute complex in Drosophila larvae. Genes \& Dev. 1: 297-306.

Dixon, J.E. and C.R. Kintner. 1989. Cellular contacts required for neural induction in Xenopus embryos: Evidence for two signals. Development 106: 749-757.

Doe, C.Q. and C.S. Goodman. 1985. Early events in insect neurogenesis. II. The role of cell interactions and cell lineages in the determination of neuronal precursor cells. Dev. Biol. 111: 206-219.

Doyle, H.J., K. Harding, T. Hoey, and M. Levine. 1986. Transcripts encoded by a homeobox gene are restricted to dorsal tissues of Drosophila embryos. Nature 323: 76-79.

Doyle, H.J., R. Kraut, and M. Levine. 1989. Spatial regulation of zerknullt: A dorsal-ventral patterning gene in Drosophila. Genes \& Dev. 3: 1515-1533.

Ghysen, A. and C. Dambly-Chaudiere. 1988. From DNA to form: The achaete-scute complex. Genes \& Dev. 2: 495501.

Godsave, S.F. and J.M.W. Slack. 1991. Single cell analysis of mesoderm formation in the Xenopus embryo. Development 111: 523-530.

Gonzalez, F., S. Romani, P. Cubas, J. Modolell, and S. Campuzano. 1989. Molecular analysis of the asense gene, a member of the achaete-scute complex of Drosophila melanogaster and its novel role in optic lobe development. EMBO $\%$. 8: 3553-3562.

Green, J.B.A. and J.C. Smith. 1990. Graded changes in dose of a Xenopus activin A homologue elicit stepwise transitions in embryonic cell fate. Nature 347: 391-394.

Gurdon, J.B. 1987. Embryonic induction-molecular prospects. Development 99: 285-306.

Haenlin, M., B. Kramatschek, and J.A. Campos-Ortega. 1990. The pattern of transcription of the neurogenic gene Delta of Drosophila melanogaster. Development 110: 905-914.

Hamburger, V. 1988. The heritage of experimental embryology: Hans Spemann and the organizer. Oxford University Press, Cambridge.

Heitzler, P. and P. Simpson. 1991. The choice of cell fate in the epidermis of Drosophila. Cell 64: 1083-1092.

Hemmati-Brivanlou, A.H. and R.M. Harland. 1989. Expression of an engrailed-related protein is induced in the anterior neural ectoderm of early Xenopus embryos. Development 106: 611-617.

Jan, L.Y. and Y.N. Jan. 1982. Antibodies to horseradish peroxidase as specific neuronal markers in Drosophila and in grasshopper embryos. Proc. Natl. Acad. Sci. 72: 2700-2704.

Jimenez, J. and J. Campos-Ortega. 1990. Defective neuroblast committment in mutants of the achaete-scute complex and adjacent genes of Drosophila melanogaster. Neuron 5: 8189.

Jones, E.A. and H.R. Woodland. 1989. Spatial aspects of neural induction in Xenopus laevis. Development 107: 785-792.

Kidd, S., M.R. Kelley, and M.W. Young. 1986. Sequence of the Notch locus of Drosophila melanogaster: Relationship of the encoded protein to mammalian clotting and growth factors. Mol. Cell. Biol. 6: 3094-3108.

Kintner, C.R. and D.A. Melton. 1987. Expression of Xenopus $\mathrm{N}$-CAM in ectoderm is an early response to neural induction. Development 99: 311-325.

Klambt, C., J.R. Jacobs, and C.S. Goodman. 1991. The midline of the Drosophila central nervous system: A model for the genetic analysis of cell fate, cell migration and growth cone guidance. Cell 64: 801-815.

Knust, E., K. Tietze, and J.A. Campos-Ortega. 1987. Molecular analysis of the neurogenic locus Enhancer of split of Drosophila melanogaster. EMBO J. 6: 4113-4123.

Kopczynski, C.C., A.K. Alton, K. Fechtel, P.J. Kooh, and M.A.T. Muskavitch. 1988. Delta, a Drosophila neurogenic gene, is transcriptionally complex and encodes a protein related to blood coagulation factors and epidermal growth factor of vertebrates. Genes \& Dev. 2: 1723-1735.

Lehmann, R., U. Dietrich, F. Jimenez, and J.A. Campos-Ortega. 1983. On the phenotype and development of mutants of early neurogenesis in Drosophila melanogaster. Wilhelm Roux's Arch. Dev. Biol. 192: 62-74.

Leptin, M. and B. Grunewald. 1990. Cell shape changes during gastrulation in Drosophila. Development 110: 73-84.

Nambu, J.R., R.G. Franks, S. Hu, and S.T. Crews. 1990. The single-minded gene of Drosophila is required for the expression of genes important for the development of CNS midline cells. Cell 63: 63-75.

Poulson, D.F. 1950. Histogenesis, organogenesis and differentiation in the embryo of Drosophila melanogaster. In Biology of Drosophila (ed. M. Demerec), pp. 168-274. Wiley, New York.

Preiss, A., D.A. Hartley, and S. Artavanis-Tsakonas. 1988. The molecular genetics of Enhancer of split, a gene required for embryonic neural development in Drosophila. EMBO $J$. 7: 3917-3928.

Rao, Y., L. Jan, and Y.N. Jan. 1990. Similarity of the product of the Drosophila neurogenic gene big brain to transmembrane channel proteins. Nature 345: 163-167.

Romani, S., S. Campuzano, and J. Modolell. 1987. The achaetescute complex is expressed in the neurogenic regions of Drosophila embryos. EMBO J. 6: 2085-2092.

Roth, S., D. Stein, and C. Nüsslein-Volhard. 1989. A gradient of nuclear localization of the dorsal protein determines dorsoventral pattern in Drosophila embryo. Cell 59: 1189-1202.

Ruiz i Altaba, A. 1990. Neural expression of the Xenopus homeobox gene Xhox3: Evidence for a patterning neural signal that spreads through the ectoderm. Development 108: 595604.

Rushlow, C.A., K. Han, J.L. Manley, and M. Levine. 1987. The graded distribution of the dorsal morphogen is initiated by selective nuclear transport in Drosophila. Cell 59: 11651177. 
Simpson, P. 1983. Maternal-zygotic gene interactions during formation of the dorsoventral pattern in Drosophila embryos. Genetics 105: 615-632.

Sharpe, C.R. and J.B. Gurdon. 1990. The induction of anterior and posterior neural genes in X. laevis. Development 109: $765-774$.

Sharpe, C.R., A. Fritz, E.M. De Robertis, and J.B. Gurdon. 1987. A homeobox containing marker of posterior neural differentiation shows the importance of predetermination in neural induction. Cell 50: 749-758.

Spemann, H. 1938. Embryonic development and enduction. Yale University Press, New Haven.

Spemann, H. and H. Mangold. 1924. Induction of embryonic primordia by implantation of organizers from a different species. Arch. Mikrosk. Anat. Entwicklungsmech 100: 599638. Translated by V. Hamburger. 1964. Foundations of experimental embryology (ed. B.H. Willier and J.M. Oppenheimer). Prentice-Hall, Englewood Cliffs, New Jersey.

Steward, R. 1989. Relocalization of the dorsal protein from cytoplasm to the nucleus correlates with its function. Cell 59: $1179-1188$.

Tautz, D. and D. Pfeifle. 1989. A nonradioactive in situ hybridization method for the localization of specific RNAs in Drosophila embryos reveals a translational control of the segmentation gene hunchback. Chromosoma 98: 81-85.

Thisse, B., C. Stoetzel, T.C. Gorostiza, and F. Perin-Schmitt. 1988. Sequence of the twist gene and nuclear localization of its protein in endomesodermal cells of early Drosophila embryos. EMBO /. 7: 2175-2183.

Vaessin, H., K.A. Bremer, E. Knust, and J.A. Campos-Ortega. 1987. The neurogenic locus Delta of Drosophila melanogaster is expressed in neurogenic territories and encodes a putative transmembrane protein with EGF-like repeats. $E M B O$ I. 6: 3431-3440.

Villares, R. and C.V. Cabrera. 1987. The achaete-scute gene complex of D. melanogaster: Conserved domains in a subset of genes required for neurogenesis and their homology to myc. Cell 50: 415-424.

Wharton, K.A., K.M. Hohansen, T. Xu, and S. Artavanis-Tsakonas. 1985. Nucleotide sequence from the neurogenic locus Notch implies a gene product that shares homology with proteins containing EGF-like repeats. Cell 43: 567-581.

Yamada, T., M. Placzek, H. Tanaka, J. Dodd, and T.M. Jessell. 1991. Control of cell pattern in the developing nervous system: Polarizing activity of the floor plate and notochord. Cell 64: 635-647.

Yedbovnick, B., D. Smoller, P. Young, and D. Mills. 1988. Molecular analysis of the neurogenic locus mastermind of Drosophila melanogaster. Genetics 118: 483-497.

Ziemer, A., K. Tietze, E. Knust, and J.A. Campos-Ortega. 1988. Genetic analysis of Enhancer of split, a locus involved in neurogenesis in Drosophila melanogaster. Genetics 119: 6374. 


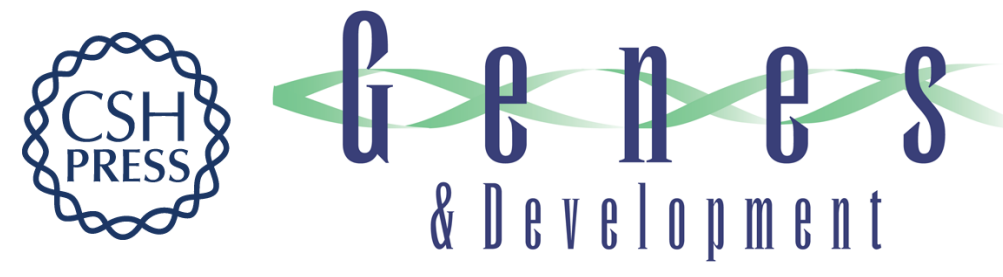

\section{Neuroectoderm in Drosophila embryos is dependent on the mesoderm for positioning but not for formation.}

Y Rao, H Vaessin, L Y Jan, et al.

Genes Dev. 1991, 5:

Access the most recent version at doi:10.1101/gad.5.9.1577

References This article cites 54 articles, 19 of which can be accessed free at: http://genesdev.cshlp.org/content/5/9/1577.full.htmI\#ref-list-1

License

Email Alerting

Receive free email alerts when new articles cite this article - sign up in the box at the top Service right corner of the article or click here.

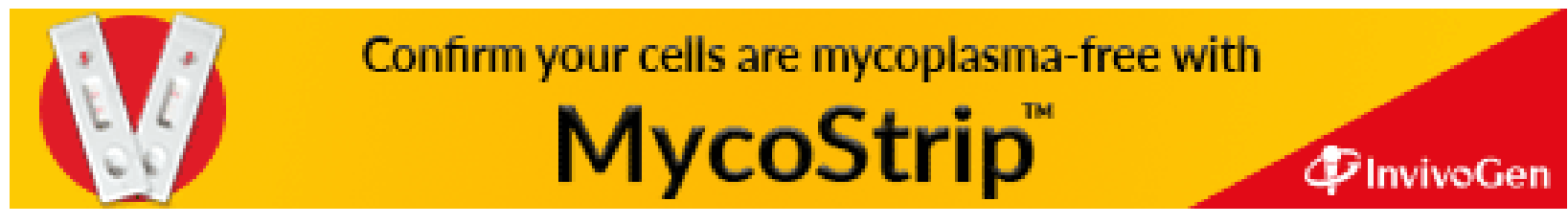

